\title{
Tiagabine: efficacy and safety in partial seizures - current status
}

\author{
Jürgen Bauer \\ Déirdre Cooper-Mahkorn
}

Department of Epileptology, Bonn University Hospital, Germany
Correspondence: Jürgen Bauer

Department of Epileptology, Bonn

University Hospital, Sigmund Freud Str. 25,

D-53 105 Bonn, Germany

Tel +49 228287 I 6954

Fax +49 $228287 \quad 14486$

Email juergen.bauer@ukb.uni-bonn.de

\begin{abstract}
Tiagabine hydrochloride (TGB) is a selective gamma-aminobutyric acid (GABA) reuptake inhibitor. TGB is effective as an add-on medication in adults and children 12 years and older in the treatment of partial seizures. Results of nonrandomized add-on trials with TGB show treatment success with seizure reduction of at least $50 \%$ in $33 \%$ to $46 \%$ of patients. In newly diagnosed patients with partial epilepsy, TGB monotherapy was as effective as carbamazepine. Comedication with TGB elevates the risk of nonconvulsive status $(7.8 \% \mathrm{vs} 2.7 \%$ without TGB). The most common side effects include dizziness/lightheadedness, asthenia/lack of energy and somnolence. TGB has no negative effects on cognition; it does not increase the risk of fractures or rash. TGB may interfere with color perception. TGB presents an intermediate risk for depression in patients with epilepsy (approximately 4\%). Regarding the risk of overdose, 96-680 mg TGB (mean $224 \mathrm{mg}$ ) caused seizures or coma. TGB is an antiepileptic drug exhibiting a specific anticonvulsive mechanism of action, the efficacy of which is relatively low when used in comedication. Critical side effects, such as the induction of nonconvulsive status epilepticus, further limit its use.
\end{abstract}

Keywords: epilepsy, tiagabine, antiepileptic drugs, status epilepticus, pharmacotherapy

\section{Introduction}

Tiagabine hydrochloride (TGB) is a selective gamma-aminobutyric acid (GABA) reuptake inhibitor. It increases synaptic GABA availability via inhibition of the GAT-1 GABA transporter on presynaptic neurons and glial cells. By these means, TGB prevents the propagation of neuronal impulses that contribute to seizures (Sommerville 1997). TGB is licensed as an add-on therapy in adults and children 12 years and older in the treatment of partial seizures (Bialer et al 2007).

In the era of highly potent newer antiepileptic drugs (AEDs), and in view of current competition, TGB has gained the reputation of being a less effective agent in the design of combined treatment in focal epilepsies. The following will illustrate advantages and limitations of treatment with this substance from a clinical point of view.

\section{Clinically relevant pharmacological aspects}

TGB is metabolized by the hepatic cytochrome $\mathrm{P} 450$ system, resulting in the formation of 5-oxo-TGB, a major urinary metabolite (Sommerville 1997). TGB itself does not appear to induce or inhibit hepatic microsomal enzyme systems and hence does not interact with oral contraceptives (Harden and Leppik 2006). In vitro studies have shown that TGB in plasma is $>95 \%$ bound to protein. The addition of phenytoin, carbamazepine, or phenobarbital does not displace TGB from plasma proteins. Valproate causes a small but statistically significant reduction in binding from $96.3 \%$ to 94.8\%. TGB does not displace valproate, phenytoin, carbamazepine, or phenobarbital (Gustavson et al 1995; Bialer et al 2007). 
AEDs with enzyme-inducing effects have an impact on the pharmacokinetics of TGB. Results of studies indicate that the AUC (area under curve) of TGB is significantly lower and the elimination half-life shorter in patients taking enzyme-inducing AED than in healthy subjects receiving only TGB or in patients taking valproate (Richens et al 1991). TGB has no impact on pharmacokinetics of carbamazepine or phenytoin, but significantly alters $\mathrm{C}_{\max }$ and $\mathrm{AUC}$ of valproate (Gustavson et al 1995).

No systematic information is available on the pharmacokinetics of TGB during pregnancy (Tomson and Battino 2007).

\section{Anticonvulsant efficacy Monotherapy}

In newly diagnosed patients with partial epilepsy, the time to withdrawal for any reason, or the time to the first seizure during a 140 -week assessment period did not significantly differ between those receiving TGB ( $n=42$; final mean dose $16.2 \mathrm{mg}$ ) or carbamazepine ( $\mathrm{n}=42$; final mean dose $640 \mathrm{mg}$ ) (Bialer et al 2007).

In patients with chronic partial seizures, a double-blind study was conducted to evaluate two regimens (5 or $10 \mathrm{mg} /$ day weekly increment) for switching current medication to TGB monotherapy. 11/20 patients from the slow titration group and $12 / 20$ of the fast titration group successfully switched to TGB monotherapy (mean dosage $13.5 \mathrm{mg}$ and $15.8 \mathrm{mg}$, respectively). Patients with fast titration had greater median percentage reduction of seizure frequency. The anticonvulsant effect was maintained during the 48 week follow-up evaluation period (Bialer et al 2007).

\section{Add-on therapy}

The studies performed previous to licensing showed a significant effect of TGB in reducing the frequency of focal and secondary generalized seizures in comparison with placebo (Lassen 1994). In a placebo-controlled parallel group study (TGB 16, 32, or $56 \mathrm{mg}$ ) the two highest doses proved to be more significantly efficacious than placebo (Rowan et al 1994). The anticonvulsive efficacy of the lowest dose of $32 \mathrm{mg}$ TGB is improved by elevating the dose (Rowan et al 1994; Bauer et al 1995).

Upon comparison of TGB with other AEDs, no difference could be observed in the evaluation of seizure freedom, since there was no study to be found in which seizure freedom was achieved with TGB (Gazzola et al 2007).
In application studies performed following licensing of TGB, data analysis proves to be variable. Results of nonrandomized add-on studies with TGB show treatment success with seizure reduction of at least $50 \%$ in $33 \%$ to $35 \%$ of patients (Lassen 1994; Crawford et al 2001), with a median dose of $35 \mathrm{mg}$ and in $46 \%$ of patients with a median dose of $46 \mathrm{mg}$ (Lassen 1994).

Jedrzejczak's (2005) results were the most optimistic. $71.4 \%$ of his patients achieved at least $50 \%$ reduction of seizure frequency through TGB dosed between 30 and $50 \mathrm{mg}$ (no mean given). Its anticonvulsive effect was most pronounced in comedication with valproate, less with carbamazepine, a result we could not reproduce in an own study (Bauer et al 2002).

Retrospective studies are less optimistic (Chahem and Bauer 2007; Table 1). $13.2 \%$ of patients achieved halving of seizure frequency with a mean TGB dose of $32 \mathrm{mg}$, an effect which was observed for a mean treatment duration of 15.5 months.

Other studies recorded outcome parameters that were more difficult to compare. A median TGB dose of $30 \mathrm{mg}$ over a median period of 3 months recorded a reduction of median seizure frequency from 4.5 to 2 per month (Bauer et al 2002). Depending on the dose of TGB $40 \mathrm{mg}$ TGB yielded 23\%-33\% seizure reduction (median) over a period of 3 months (Arroyo et al 2005). The recording of seizure control as a concomitant result of neuropsychological testing on comedication with TGB versus topiramate over a period of 6 months was also published (Fritz et al 2005). Both AEDs had a similar effect in reducing seizure frequency in this study.

In the analysis of long-term efficacy of AEDs there were not any studies in which TGB leads to seizure freedom of at least 6 months (Zaccara et al 2006).

In a comparison of combined treatment with various AEDs in patients at the Department of Epileptology at Bonn University Hospital, the efficacy of TGB is more easily evaluable, since patients do not vary in their clinical characteristics. In retrospectively analyzed data, the efficacy of TGB is low compared to other AEDs (Table 2).

\section{Anticonvulsive effect and type of seizure}

Differentiated analysis of the efficacy of TGB on various types of seizures uncovers differences. In the evaluation of 574 patients, TGB given as comedication reaches a median reduction of general seizure frequency from 4.5 to 2 seizures per month. Complex partial seizures were reduced by a median from 2 to 1 per month, simple 
Table I Combined treatment with tiagabine: clinical data and treatment results

\begin{tabular}{|c|c|c|}
\hline \multicolumn{3}{|c|}{ Clinical data of all patients involved $(n=53)$} \\
\hline Sex & Men 26 (49\%) & Women 27 (51\%) \\
\hline Age (last contact) & $19-68$ years (mean 38 years) & \\
\hline Type of epilepsy & All patients with symptomatic/cryptogenic epilepsies & \\
\hline Duration of illness $(n=37)$ & I-57 years (mean 24 years) & \\
\hline Additional antiepileptic drugs & $1-4($ mean 2.6$)$ & \\
\hline Duration of treatment & I-72 months (mean 12 months) & \\
\hline \multicolumn{3}{|c|}{ Patients with $\geq 50 \%$ seizure reduction $(n=6)$ or seizure freedom $(n=I)$} \\
\hline Maximum dose of tiagabine/day & $22.5-45 \mathrm{mg}$ (mean $32.9 \mathrm{mg}$ ) & \\
\hline Comedication & I-4 Antiepileptic drugs (mean 2.3) & \\
\hline \multirow[t]{3}{*}{ Duration of efficacy } & Seizure freedom $(n=1) 6$ years & \\
\hline & Seizure reduction $(n=6) 2-24$ months (mean 15.5 months) & \\
\hline & Loss of efficacy in 3 patients after I8-24 months (mean 20.7) & \\
\hline \multicolumn{3}{|c|}{ Patients with $<50 \%$ seizure reduction $(n=36)$ or seizure increase $(n=10)$} \\
\hline Maximum dose of tiagabine/day & $10-60$ mg (mean 37.1 mg) & \\
\hline \multirow[t]{3}{*}{ Comedication } & $1-4($ mean 2.6$)$ & \\
\hline & 20 with levetiracetam & \\
\hline & I8 with clobazam & \\
\hline Duration of treatment & I-48 months (mean 10 months) & \\
\hline \multicolumn{3}{|l|}{ Side effects $(n=28 / 53)$} \\
\hline \multicolumn{2}{|c|}{ Central nervous complaints with dizziness, headache, reduced concentration, affected speech and confusion } & 18 \\
\hline \multicolumn{2}{|l|}{ Sedation } & 5 \\
\hline \multicolumn{2}{|l|}{ Nonconvulsive status epilepticus } & 5 \\
\hline \multicolumn{2}{|l|}{ Gastrointestinal side effects } & 2 \\
\hline
\end{tabular}

After Chahem and Bauer 2007.

partial seizures from 5 to 3 per month, and generalized tonic-clonic seizures from four to one per month (Bauer et al 2002).

Jedrzejczak (2005) found a better effect of TGB in the treatment of simple and complex partial seizures than in generalized tonic-clonic seizures. Between the fourth and 16th week of TGB treatment, the number of patients with at least $50 \%$ seizure reduction increased from $38.9 \%$ to $71.4 \%$. An increase of $25.2 \%$ to $41.1 \%$ was observed for generalized tonic-clonic seizures.

\section{Seizure-inducing effects}

Nonconvulsive focal status epilepticus was a fairly common observation after licensing of TGB (Vinton et al 2005). Additionally, patients without epilepsy treated with this drug experienced first onset epileptic seizures (Jette et al 2006; Haddad et al 2007).

In a retrospective analysis of patients treated in Chalfont Epilepsy Center, London between 1997 and 2000, nonconvulsive status epilepticus was observed in 7 out of 90 patients $(7.8 \%)$ treated with TGB (mean dosage $36 \mathrm{mg}$ ), and in 32 out of 1165 patients without TGB (2.7\%) (Koepp et al 2005). In our own retrospective study, 5 out of 53 patients with TGB comedication (9.4\%) experienced nonconvulsive status epilepticus (Chahem and Bauer 2007).

\section{General tolerability and overdosage}

The most common side effects associated with TGB are dizziness/lightheadedness, asthenia/lack of energy, somnolence, nausea, nervousness/irritability, tremor, abdominal pain, and thinking abnormal/difficulty with concentration or attention (Bialer et al 2007).

In a study concerning 53 patients receiving TGB as comedication, side effects occurred in 28 out of 53 patients (52.8\%) (Table 1). Those patients showing side effects were treated with a mean TGB dose of $36.6 \mathrm{mg}$, while patients who did not experience side effects had received an average of $36.5 \mathrm{mg}$. As comedication, those patients with sides effects had received between 1 and 4 (mean 2.5) additional AEDs 
Table 2 Tiagabine add-on treatment of focal epilepsies in adults

\begin{tabular}{|c|c|c|c|c|c|c|}
\hline Reference & $\begin{array}{l}\text { Patients } \\
\text { (total number) }\end{array}$ & $\begin{array}{l}\text { Tiagabine } \\
\text { dosage }\end{array}$ & $\begin{array}{l}\text { Study } \\
\text { period }\end{array}$ & Aim of study & $\begin{array}{l}\text { Study outcome } \\
\text { (if others than } \\
\text { seizure reduction) }\end{array}$ & Seizure outcome \\
\hline $\begin{array}{l}\text { Bauer et al } \\
1995\end{array}$ & 17 & $\begin{array}{l}\text { I2-64 mg } \\
\text { (mean not given) }\end{array}$ & $\begin{array}{l}\text { At least } 6 \\
\text { months }\end{array}$ & $\begin{array}{l}\text { Seizure reduction }>50 \% \\
\text { vs baseline }\end{array}$ & Not applicable & $\begin{array}{l}>50 \% \text { Seizure reduction } \\
\text { TGB I2-24 mg: 8/I7 (47\%) } \\
\text { TGB 26-36 mg: 5/I5 (33\%) } \\
\text { TGB 38-48 mg: 4/8 (50\%) } \\
\text { TGB 52-64 mg: 2/3 }\end{array}$ \\
\hline $\begin{array}{l}\text { Bauer et al } \\
2002\end{array}$ & 574 & $\begin{array}{l}29.1 \text { mg (mean; } \\
\text { range not given) }\end{array}$ & $\begin{array}{l}94.9 \pm 42.7 \\
\text { days }\end{array}$ & Mean seizure reduction & Not applicable & $\begin{array}{l}\text { Decrease of total seizure } \\
\text { frequency from } 4.5 \text { to } 2.0 \\
\text { seizures/month } \\
\text { Seizure free at the end of } \\
\text { study period: } 12.3 \%\end{array}$ \\
\hline $\begin{array}{l}\text { Arroyo et al } \\
2005\end{array}$ & 243 & $40 \mathrm{mg}$ & 12 weeks & Comparison bid vs tid & $\begin{array}{l}\text { Fewer patients with } \\
\text { b.i.d completed the } \\
\text { study }\end{array}$ & $\begin{array}{l}\text { Median percentage } \\
\text { decrease of all seizure types } \\
33.4 \% \text { (bid) } \\
23.8 \% \text { (tid), ns }\end{array}$ \\
\hline $\begin{array}{l}\text { Jedrzejczak } \\
2005\end{array}$ & 330 & $\begin{array}{l}30-50 \mathrm{mg} \\
\text { (mean not given) }\end{array}$ & 16 weeks & $\begin{array}{l}\text { Seizure reduction }>50 \% \\
\text { vs baseline }\end{array}$ & $\begin{array}{l}\text { Seizure control was } \\
\text { significantly better } \\
\text { with VPA }\end{array}$ & $\begin{array}{l}>50 \% \text { Seizure reduction } \\
\text { All patients: } 71.4 \%\end{array}$ \\
\hline $\begin{array}{l}\text { Chahem and } \\
\text { Bauer } 2007\end{array}$ & 53 & $\begin{array}{l}10-60 \mathrm{mg} \\
\text { (mean } 36.5 \mathrm{mg} \text { ) }\end{array}$ & $\begin{array}{l}\text { I-7 months } \\
\text { (mean } 12 \\
\text { months) }\end{array}$ & $\begin{array}{l}\text { Seizure reduction }>50 \% \\
\text { vs baseline }\end{array}$ & & $\begin{array}{l}>50 \% \text { Seizure reduction: } \\
7 / 53(13.2 \%) \\
\text { including I patient with } \\
\text { seizure control for } 6 \text { years }\end{array}$ \\
\hline
\end{tabular}

Abbreviations: TGB, tiagabine; bid, twice daily; ns, not significant; tid, three times daily;VPA, valproate.

(14 with Levetiracetam, nine with oxcarbazepine, topiramate or clobazam) (Chahem and Bauer 2007).

In a pooled analysis of two studies in newly diagnosed patients with partial seizures, there were no detrimental effects on cognition after 52 weeks of TGB (20-30 mg) in monotherapy; this was similar to the results with carbamazepine (400-800 mg) monotherapy (Äikiä et al 2006). In a combined study, TGB did not show any negative influence on neuropsychological performance of the frontal lobe (Fritz et al 2005).

In a study on 20 patients with focal epilepsy, TGB monotherapy did not have an effect on visual contrast sensitivity, but may interfere with colour perception (7/17 patients, $41 \%$ ). There was no evidence of visual field defects (Sorri et al 2005).

TGB presents an intermediate risk for depression in patients with epilepsy (about 4\%) (Mula and Sander 2007) and does not elevate the risk of fractures of patients treated with this substance (Vestergard et al 2004). Treatment with TGB did not coincide with an elevated risk of developing drug-induced rashes (Arif et al 2007). A case report described a transient episode of athetosis induced by TGB in a patient with symptomatic epilepsy (Tombini et al 2006).
Fifty-seven patients (mean age 30.5 years) with TGB overdosage were analyzed. The mean onset and duration of symptoms were 1.3 hours and 9.1 hours, respectively. The mean dose of patients with and without symptoms was $102 \mathrm{mg}$ and $10 \mathrm{mg}$, respectively. The mean dose for patients experiencing seizures was $224 \mathrm{mg}$ (range 96-680 mg), and the mean dose for patients with respiratory depression and coma was $270 \mathrm{mg}$ (range 96-680 mg) (Cantrell et al 2004; Spiller et al 2005). Acute treatment of seizures is with benzodiazepines. In addition, daily dosage of TGB has to be reduced.

\section{Discussion}

The main indication for prescription of TGB is the add-on treatment of patients with previously pharmacoresistant focal epilepsies for which this agent is licensed. Even if its mechanism of action may suggest an additive efficiency of AED of other action mechanisms, TGB in its clinical use has not been established as an agent of first or second choice (Bauer and Reuber 2003). A significant contributing factor to this fact is the lack of efficacy in achievement of seizure freedom - the final item in the assessment of an AED (Bauer et al 2008). Despite the low quota of seizure freedom with 
other AED in comedication of chronic focal epilepsies, eg, for levetiracetam 6.6\% (Bauer et al 2006); the success of each patient does influence the intuitive ranking of AED by doctor and patient alike. The low efficacy of TGB in this treatment phase becomes particularly obvious in the most recent study by Gazzolla et al (2007). In this study, seizure freedom analyses achieved during clinical trials included both patients who completed the trial, and those who dropped out prior to completion. No study that proved this for TGB was found. For other AEDs, rates of seizure freedom were $0.8 \%$ (trial completed) versus $0.7 \%$ (drop out) (lamotrigine), $2.6 \%$ versus $12 \%$ (oxcarbazepine), $3.9 \%-7.1 \%$ versus $3.6 \%-6.4 \%$ (levetiracetam), $1.3 \%-1.4 \%$ versus $3.0 \%-7.9 \%$ (pregabalin), and 3.0\%-6.0\% (zonisamide).

Even upon comparison with other AEDs of third choice, such as felbamate, sulthiame or pregabalin, the successes of TGB seem comparatively low (Table 3 ). Upon comparison with highly potent agents such as topiramate, the substance cannot reach comparable results, even if the findings in a neuropsychologically orientated study may suggest this (Fritz et al 2005).

Tolerability remains a problematic issue. In comparison with felbamate and sulthiame, TGB appeared to have the highest rate of side effects and the lowest anticonvulsant effect (Table 3). The induction of nonconvulsive status epilepticus has significantly contributed to TGB's bad reputation (Bauer 1996; Koepp et al 2005; Chahem and Bauer 2007).
Once the decision to treat with this agent has been made, TGB must be slowly introduced with a dose elevation of $5 \mathrm{mg}$ per week. Suitably high doses should be aimed for (at least 45-60 mg), since dose elevation has been proven to enhance its effect. TGB should be taken three times a day, which appears to be most efficient from an anticonvulsive point of view (Arroyo et al 2005; Table 2). In combination with carbamazepine, our experience shows that cerebellar side effects must be expected when both agents are given in higher doses. We cannot identify a considerable advantage or disadvantage in the comedication of TGB with a particular AED.

The results of treatment of newly diagnosed epilepsies with TGB in monotherapy are more optimistic. In this context TGB appeared to be as efficacious as carbamazepine. Currently, TGB is not licensed for this indication.

In summary, TGB is an AED which exerts a specific mechanism of action with an efficacy which is relatively low in comedication. Critical side effects such as the induction of non-convulsive status epilepticus limit its use. Possibly the establishment of its licencing for monotherapy is a chance to give this AED a broader range of prescription.

\section{Conflict of interest}

J. Bauer has received remuneration for lectures from various pharmaceutical companies in the past years. However, Cephalon, the manufacturer Tiagabine was not among them.

Table 3 Efficacy of add-on treatment in focal epilepsy

\begin{tabular}{|c|c|c|c|c|c|}
\hline & Topiramate & Pregabalin & Felbamate & Tiagabine & Sulthiame \\
\hline $\begin{array}{l}\text { Number of patients } \\
\text { (men/women) }\end{array}$ & $98(42 / 56)$ & $98(55 / 43)$ & $41(25 / 16)$ & $53(26 / 27)$ & $28(14 / 14)$ \\
\hline Age in years (mean) & $3-70.6(33.6)$ & $15-70(37)$ & $8-54(29)$ & 19-68 (38) & $18-57(32.6)$ \\
\hline $\begin{array}{l}\text { Duration of epilepsy in } \\
\text { years (mean) }\end{array}$ & $\mathrm{I}-55.5(\mathrm{I} 6.2)$ & Not given & $5-40(25)$ & $\mathrm{I}-57(24)$ & $9-48(24.9)$ \\
\hline Additional AED (mean) & $0-5(1.7)$ & $\mathrm{I}-5(2.7)$ & $0-6(2.4)$ & $\mathrm{I}-4(2.6)$ & $0-5(2.5)$ \\
\hline $\begin{array}{l}\text { Duration (in years) of } \\
\text { treatment with the AED } \\
\text { evaluated (mean) }\end{array}$ & $\begin{array}{l}87 \text { patients with complete } \\
\text { follow-up } 0.5-24 \text { months (I } 3.6) \\
\text { I I patients without complete } \\
\text { follow-up } 8.9 \text { - I } 7.6 \text { months (I4.4) }\end{array}$ & $\begin{array}{l}32<3 \text { months } \\
34: 3-12 \text { months } \\
32: 12 \text { months }\end{array}$ & $\mathrm{I}-72$ months (I8) & I-72 months (I2) & I-I56 months (30.6) \\
\hline $\begin{array}{l}\text { Reduction of seizure } \\
\text { frequency by at least } 50 \% \\
\text { (without complete seizure } \\
\text { control) }\end{array}$ & 14 (|4.2\%) & $8 / 94 *(8.5 \%)$ & $8 / 41$ (19.5\%) & $6 / 53(11.3 \%)$ & $5 / 28(17.8 \%)$ \\
\hline Complete seizure control & 14 (|4.3\%) & - & I/4I (2.4\%), for 6 years & $\begin{array}{l}1 / 53(1.8 \%), \text { for } \\
6 \text { years }\end{array}$ & - \\
\hline
\end{tabular}

After Bauer and Ruocco 2006; Chahem and Bauer 2007; Beerlage and Bauer 2007.

*no follow-up in 4 patients.

Abbreviation: AED, antiepileptic drug. 
D. Cooper-Mahkorn did not receive any remuneration from the pharmaceutical industry.

\section{References}

Aikiä M, Jutila L, Salmenperä T, et al. 2006. Comparsion of the cognitive effects of tiagabine and carbamazepine as monotherapy in newly diagnosed adult patients with partial epilepsy: pooled analysis of two long-term, randomized, follow-up studies. Epilepsia, 47:1121-7.

Arif H, Buchsbaum R, Weintraub D, et al. 2007. Comparison and predictors of rash associated with 15 antiepileptic drugs. Neurology, 68:1701-9.

Arroyo S, Boothman BR, Brodie MJ, et al. 2005. A randomized open-label study of tiagabine given two or three times daily in refractory epilepsy. Epilepsy Behav, 14:81-4.

Bauer J. 1996. Seizure inducing effects of antiepileptic drugs. Acta Neurol Scand, 94:367-77.

Bauer J, Reuber M. 2003. Medical treatment of epilepsy. Expert Opin Emerg Drugs, 8:457-67.

Bauer J, Ruocco A. 2006. Epilepsy therapy with pregabalin. Treatment follow-up in 103 patients (in German). Aktuel Neurol, 33:439-441.

Bauer J, Stawowy B, Lenders T, et al. 1995. Efficacy and tolerabilty of tiagabine: Results of an add-on study in patients with refractory partial seizures. $J$ Epilepsy, 8:83-6.

Bauer J, Bergmann A, Reuber M, et al. 2002. Tolerability of tiagabine: a prospective open-label study. Epileptic Disord, 4:257-60.

Bauer J, Ben-Menachem E, Krämer G, et al. 2006. Levetiracetam: a long-term follow-up study of efficacy and safety. Acta Neurol Scand, 114:169-76.

Bauer J, Buchmüller L, Reuber M, et al. 2008. Which patients become seizure-free with antiepileptic drugs? An observational study in 821 patients with epilepsy. Acta Neurol Scand, 117:55-9.

Beerlage S, Bauer J. 2007. Treatment of epilepsy with topiramate. A 12and 24-months treatment analysis in 98 patients (in German). Aktuel Neurol, 34:555-8.

Bialer M, Johannessen SI, Kupferberg HJ, et al. 2007. Progress report on new antiepileptic drugs: A summary of the eighth Eilat conference (EILAT VIII). Epilepsy Res, 73:1-52.

Cantrell FL, Ritter M, Himes E. 2004. Intentional overdose with tiagabine: an unusual clinical presentation. $J$ Emerg Med, 27:271-2.

Chahem J, Bauer J. 2007. Treatment of epilepsy with third-line antiepileptic drugs: felbamate, tiagabine and sulthiame (in German). Nervenarzt, $78: 1407-12$

Crawford P, Meinardi H, Brown S, et al. 2001. Tiagabine: efficacy and safety in adjunctive treatment of partial seizures. Epilepsia, 42:531-8.

Fritz N, Glogau S, Hoffmann J, et al. 2005. Efficacy and cognitive side effcts of tiagabine and topiramate in patients with epilepsy. Epilepsy Behav, 6:373-81.

Gazzola DM, Balcer LJ, French JA. 2007. Seizure-free outcome in randomized add-on trials of the new antiepileptic drugs. Epilepsia, 48:1303-7.
Gustavson LE, Cato A, Guenther HJ, et al. 1995. Lack of clinically important drug interactions between tiagabine and carbamazepine, phenytoin or valproate. Epilepsia, 36:159.

Haddad NI, Umashankar G, Harik SI. 2007. Tiagabine-induced nonconvulsive status epilepticus in a patient without history of epilepsy. Neurosciences, 2:152-4.

Harden CL, Leppik I. 2006. Optimizing therapy of seizures in women who use oral contraceptives. Neurology, 67:S56-8.

Jedrzejczak J. 2005. Tiagabine as add-on therapy may be more effective with valproate - open label, multicentre study of patients with focal epilepsy. Eur J Neurol, 12:176-80.

Jette N, Cappell J, VanPassel L, et al. 2006. Tiagabine-induced nonconvulsive status epilepticus in an adolescent without epilepsy. Neurology, 67:1514-5.

Koepp MJ, Edwards M, Collins J, et al. 2005. Status epilepticus and tiagabine therapy revisited. Epilepsia, 46:1625-32.

Lassen LC. 1994. Phase II study of of tiagabine: efficacy and safety in adjunctive treatment of partial seizures. Novo Nordisk Clinical Study Report, TIA-103/CNS/1, October 18.

Mula M, Sander JW. 2007. Negative effects of antiepileptic drugs on mood in patients with epilepsy. Drug Saf, 30:555-67.

Richens A, Gustavson LE, McKelvy JF, et al. 1991. Parmacokinetics and safety of single-dose tiagabine $\mathrm{HCl}$ in epileptic patients chronically treated with four other antiepileptic drug regimens. Epilepsia, 32:12.

Rowan AJ, Uthman B, Ahmann P, et al. 1994. Safety and efficacy of three dose levels of tiagabine $\mathrm{HCl}$ versus placebo as adjunctive treatment for complex partial seizures. Epilepsia, 35:54.

Sommerville KW 1997. Tiagabine. In: Engel JJr, Pedley TA (eds) Epilepsy: A Comprehensive Textbook. Philadelphia: Lippincott-Raven, pp. 645-53.

Sorri I, Kälviäinen R, Mäntyjärvi M. 2005. Color vision and contrast sensitivity in epilepsy patients treated with initial tiagabine monotherapy. Epilepsy Res, 67:101-7.

Spiller HA, Winter ML, Ryan M, et al. 2005. Retrospective evaluation of tiagabine overdose. Clin Toxicol (Phila), 43:855-9.

Tombini M, Pacifici L, Passarelli F, et al. 2006. Transient athetosis induced by tiagabine. Epilepsia, 47:799-800.

Tomson T, Battino D. 2007. Pharmacokinetics and therapeutic drug monitoring of newer antiepileptic drugs during pregnancy and puerperium. Clin Pharmacokinet, 46:209-19.

Vestergaard P, Rejnmark L, Mosekilde L. 2004. Fracture risk associated with use of antiepileptic drugs. Epilepsia, 45:1330-7.

Vinton A, Kornberg AJ, Cowley M, et al. 2005. Tiagabine-induced generalised non convulsive status epilepticus in patients with lesional focal epilepsy. J Clin Neurosci, 12:128-33.

Zaccara G, Messori A, Cincotta M, et al. 2006. Comparison of the efficacy and tolerability of new antiepileptic drugs: what can we learn from long-term studies? Acta Neurol Scand, 114:157-68. 